\title{
Solitary fibrous tumor of the pleura: 3 case reports
}

\section{TUMOR FIBROSO SOLITÁRIO DE PLEURA: RELATO DE 3 CASOS}

\author{
ELIAS AMORIM ${ }^{1 *}$ \\ IPhD. Professor of the Urgency and Emergency Department of the Hospital Universitário Presidente Dutra, Universidade Federal do Maranhão (UFMA). Head of the Thoracic Surgery Department of the Hospital \\ Universitário Presidente Dutra da UFMA, São Luís, MA, Brazil
}

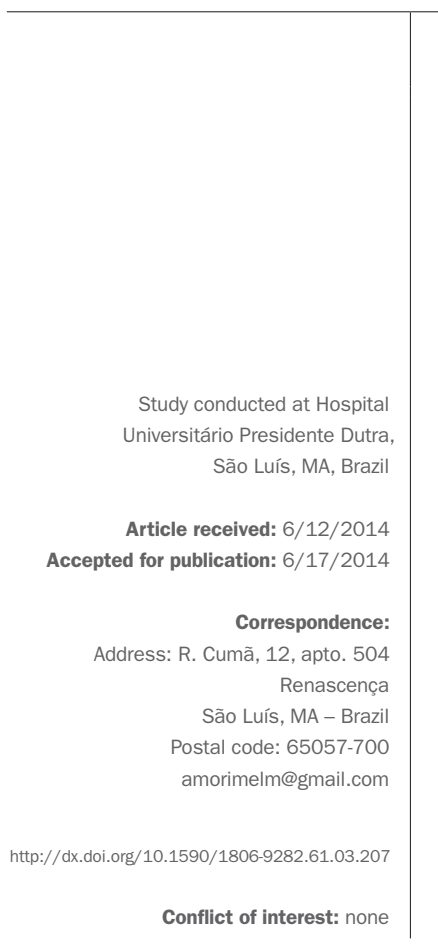

\section{INTRODUCTION}

Solitary fibrous tumor of the pleura (SFTP) is a rare tumor arising from mesenchymatous cells in submesothelial pleural tissue which, unlike mesothelioma, is not related to asbestos or smoking. ${ }^{1}$

Historically, many names have been used to designate this neoplasm because of the controversy surrounding its histogenesis. Today, the source is widely recognized as mesenchymal cells of the pleural submesothelial tissue instead of mesothelial cells.

SFTPs are often asymptomatic in their early stages and are often discovered by chance with routine chest radiography. Parts of these tumors tend to grow into massive injury before there is local compression symptoms. ${ }^{2,3}$

They affect mainly adults between the sixth and seventh decades of life with the same distribution between men and women, and represent less than $5 \%$ of all tumors of the pleura. ${ }^{1,5}$

\section{Clinical case 1}

Patient aged 55, referring mild discomfort in the right hemithorax, and with radiological image presenting large mass in the chest. Previous biopsy revealed a fibrous tumor. After surgical resection, the surgical specimen weighed $5.5 \mathrm{~kg}$ (Figure 1).

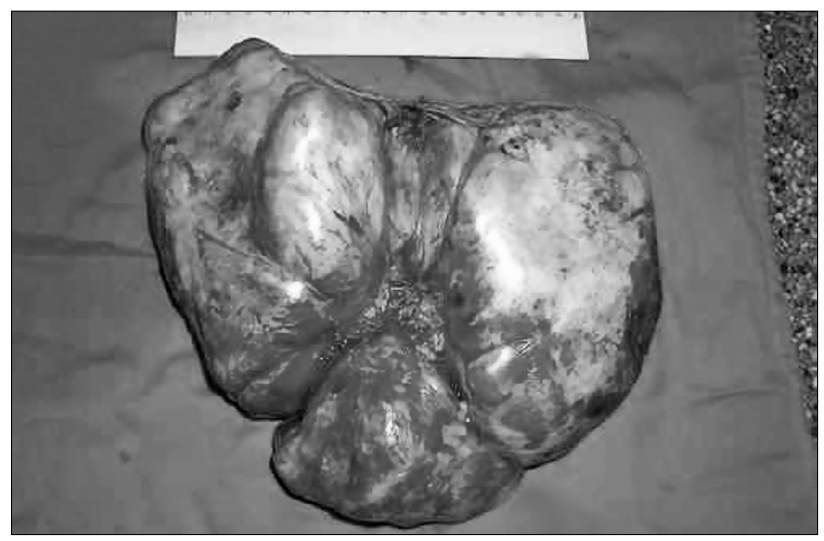

FIGURE 1 Tumor mass in the right hemithorax.

\section{Clinical case 2}

Patient aged 63 years with no history of smoking, had a persistent cough for several years and presented digital clubbing (Figure 2). Chest tomography showed a mass at the right lung base (Figure 3).

\section{Clinical case 3}

Patient aged 51 years, with no apparent complaint, underwent chest $\mathrm{X}$-ray that revealed a mass in the right hemithorax confirmed by computed tomography. 


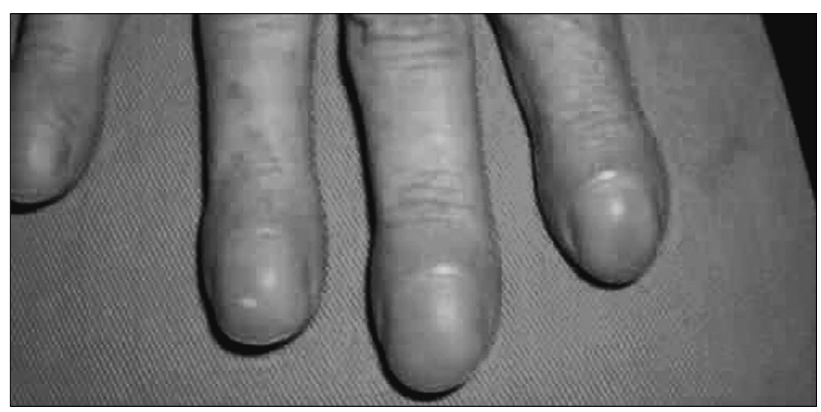

FIGURE 2 Clubbing.

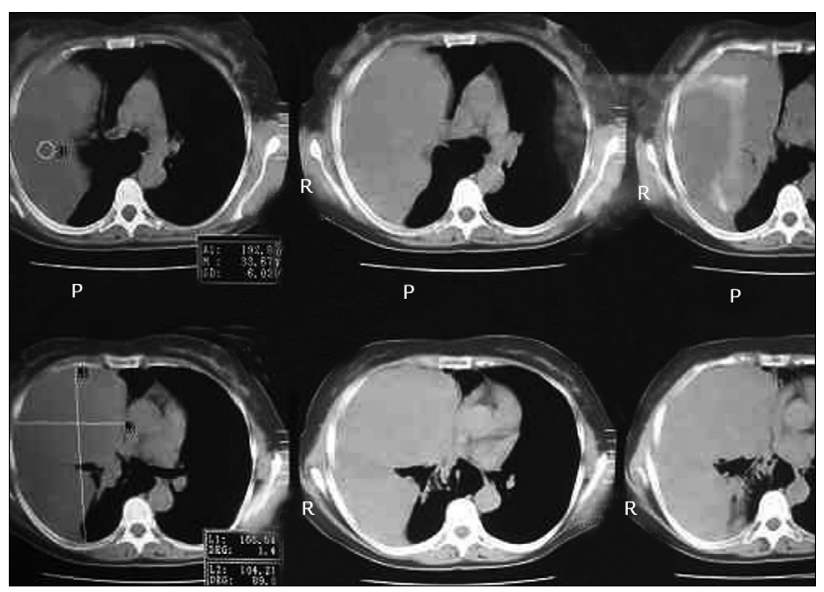

FIGURE 3 Large mass occupying the right hemithorax.

The patient underwent surgical resection, with confirmation of pathology as fibrous mesothelioma, weighing $916 \mathrm{~g}$.

\section{Discussion}

SFTPs are rare neoplasms, with slow growth. They represent less than $5 \%$ of all pleural neoplasms and have received different names because of their uncertain histogenesis and biological behavior: localized fibrous tumor of the pleura, primary mesothelioma, localized fibrous mesothelioma, benign localized fibroma, or submesothelial fibroma. ${ }^{6}$

Symptoms include cough, chest pain and dyspnea. Clubbing and hypertrophic osteoarthropathy (Pierre Marie-Bamberger syndrome) have been reported in 10 to $20 \%$ of patients. In less than five percent of the patients, the tumor may secrete insulin, which causes intractable hypoglycemia (Doege-Potter's syndrome). ${ }^{4}$

In the radiological chest image, the tumor appears as a solitary mass of well-defined borders and lobulated, with no evidence of invasion. ${ }^{7}$

\section{Conclusion}

Complete resection of the lesion is the treatment of choice in all cases. The prognosis of benign lesions is excellent, although careful late follow-up evaluation is required ${ }^{8}$ for the aggressive types, which are rare. This can be complemented by chemotherapy or radiation therapy, but the benefits have not been proven. ${ }^{9}$

\section{Resumo}

Tumor fibroso solitário de pleura: relato de 3 casos.

Introdução: o tumor fibroso solitário de pleura (TFSP) é um tumor raro com origem nas células mesenquimatosas do tecido pleural submesotelial, que, ao contrário do mesotelioma, não tem relação com asbesto ou tabagismo.

Método: relato de caso de quatro pacientes submetidos a tratamento cirúrgico para TFSP gigante e revisão da literatura pertinente.

Resultados: dos quatro pacientes operados, dois apresentaram sintomas como tosse, dores no peito e sensação de compressão enquanto os demais foram assintomáticos. Todos os pacientes foram submetidos à ressecção cirúrgica total por toracotomia posterolateral ampla, sendo os espécimes cirúrgicos removidos com mínimo sangramento. Em nenhum dos casos houve necessidade de lobectomia ou segmentectomia complementar. Todos os tumores eram histologicamente benignos.

Conclusão: a ressecção total da lesão constitui o tratamento de escolha em todos os casos de TFSP. O prognóstico de lesões benignas é excelente embora o acompanhamento seja necessário. Nas formas mais raras e agressivas, o tratamento pode incluir quimioterapia ou radioterapia adjunta, cujos benefícios ainda não foram confirmados.

Palavras-chave: tumor fibroso solitário pleural, neoplasias pleurais, pleura.

\section{REFEREnCES}

1. Nunes AP, Mendes I, Godinho T, Lourenço I, Jordão A, Clara JP. Tumor fibroso solitário da pleura. Rev Port Cir Cardio-Torác Vasc. 2007;14(4):203-5.

2. Guo J, Chu X, Sun Yu-e, Zhang L, Zhou N. Giant solitay tumor of the pleura: an analysis of five patients. World J Surg. 2010;34(11):2553-7.

3. Cardinale L, Cortese G, Familiari U, Perna M, Solitro F, Fava C. Fibrous tumour of the pleura (SFTP): a proteiform disease. Clinical, histological and atypical radiological patterns selected among our cases. Radiol Med. 2009;114(2):204-15.

4. Krishnadas R, Froeschle PO, Berrisford RG. Recurrence and malignant transformation in solitary fibrous tumour of the pleura. Thorac Cardiov Surg. 2006;54(1):65-7.

5. Fiorello A, Vicidomini G, Santini M. Giant solitary fibrous tumors of the pleura: two case reports. Thorac Cardiov Surg. 2007;55(7):458-70.

6. Cardillo G, Carbone L, Carleo F, Masala N, Graziano P. Solitary fibrous tumors of the pleura: an analysis of 110 patients treated in a single institution. Ann Thorac Surg. 2009;88(5):1632-7.

7. Parreño AJ, Pérez EP, Muñoz RD, Martinez JS. Tumor fibroso localizado de la pleura: hallazgos radiológicos. Radiologia. 2007;49(5):339-42.

8. Rakovich G, Laflamme M, Ouellette D, Beauchamp G. Solitary fibrous tumors of the pleura: a case report. Can Respir J. 2010;17(3):113-4.

9. Saint-Blancard P, Bonnichon A, Margery J. La tumeur fibreuse solitaire pleurale: à propos de cinq observations. Rev Pneumol Clin. 2009;65(3):153-8. 